\title{
Evaluation of Computed Tomography, Clinical and Laboratory Findings of COVID-19 in Cancer Patients
}

\author{
Kanser Hastalarında COVID-19 Bilgisayarlı Tomografi, Klinik ve Laboratuvar Bulgularının \\ Değerlendirilmesi
}

\author{
Tolga KÖŞECi' ${ }^{1}$ \\ (D) 0000-0002-8696-0525 \\ Ömer KAYA ${ }^{2}$ \\ (D) 0000-0001-7998-0686 \\ Okan DILLEK ${ }^{3}$ \\ (D) 0000-0002-2144-2460 \\ İran ALISSAN ${ }^{4}$ \\ (D) 0000-0002-9473-9476 \\ Veysel HAKSÖYLER \\ (D) 0000-0001-5124-8362 \\ Berna BOZKURT DUMAN ${ }^{1}$ \\ (D) 0000-0002-9889-1897 \\ Timuçin ÇíL ${ }^{1}$ \\ (D) 0000-0002-5033-1479
}

\footnotetext{
${ }^{1}$ Adana City Training and Research Hospital Department of Medical Oncology, Adana, Turkey

${ }^{2}$ Çukurova University Faculty of Medicine Department of Radiology, Adana, Turkey

${ }^{3}$ Adana City Training and Research Hospital Department of Radiology, Adana, Turkey

${ }^{4}$ Adana City Training and Research Hospital Department of Internal Medicine, Adana, Turkey
}

${ }^{5}$ Private Medline Hospital Department of Medical Oncology, Adana, Turkey

\section{Corresponding Author Sorumlu Yazar \\ Tolga KÖŞECİ \\ drtolgakoseci@gmail.com}

Received / Gelis Tarihi : 15.09.2020 Accepted / Kabul Tarihi : 11.11.2020 Available Online /

Çevrimiçi Yayın Tarihi : 25.11.2020

\begin{abstract}
Aim: The aim of this study was to evaluate the computed tomography (CT), clinical and laboratory findings of coronavirus disease 2019 (COVID-19) in cancer patients and to compare the findings between polymerase chain reaction (PCR) positive and negative patients.

Material and Methods: Twenty-three cancer patients with positive PCR tests and 22 diagnosed as COVID-19 with clinical and radiological findings were included in the study. CT images of the patients were evaluated simultaneously by two radiologists. Presence of comorbid diseases, symptoms and laboratory values were evaluated.

Results: The most common CT involvement pattern was peripheral with $88.9 \%(\mathrm{n}=40)$. Bilateral lung involvement rate was $57.8 \%(\mathrm{n}=26)$. The most common finding was ground glass opacities $(n=38,84.5 \%) .35 .6 \%(n=16)$ of these were accompanied by consolidation. Multifocal involvement was present in $62.2 \%(\mathrm{n}=28)$ of the cases. The most frequently involved lobes were lower lobes. Other relatively common findings were septal thickening, subpleural streaking, and air bronchogram. The median neutrophil, lymphocyte, D-dimer, procalcitonin, C-reactive protein and lactate dehydrogenase values of the patients were 2000 $\mathrm{mm}^{3}, 1200 \mathrm{~mm}^{3}, 1990 \mathrm{ng} / \mathrm{mL}, 30.7 \mathrm{mcg} / \mathrm{L} 15.8 \mathrm{mg} / \mathrm{dl}, 161 \mathrm{IU} / \mathrm{L}$, respectively.

Conclusion: Multifocal and bilateral involvement, and ground glass opacities were the most common findings. However, higher rates of septal thickening, which is generally less common, suggest that the findings may be more severe in cancer patients. Most of the inflammatory markers were higher in PCR negative cases. Studies with more patients in multiple centers will provide better comparison of the findings in cancer patients with the general population. Keywords: COVID-19; cancer; computed tomography; laboratory; PCR.
\end{abstract}

\section{ÖZ}

Amaç: $\mathrm{Bu}$ çalışmanın amacı kanser hastalarında koronavirus hastalığı 2019 (coronavirus disease 2019, COVID-19) bilgisayarlı tomografi (BT), klinik ve laboratuvar bulgularının değerlendirilmesi ve polimeraz zincir reaksiyonu (polymerase chain reaction, PCR) pozitif ve negatif hastaların bulgularının karşılaştırılmasıdır.

Gereç ve Yöntemler: Çalışmaya PCR testi pozitif olan 23, klinik ve radyolojik bulgularla COVID-19 tanısı almış 22 kanser hastası alındı. Hastaların BT görüntüleri iki radyolog tarafından eşzamanlı değerlendirildi. Komorbid hastalık varlığı, semptomlar ve laboratuvar değerleri değerlendirildi.

Bulgular: En sık BT tutulum paterni \%88,9 $(\mathrm{n}=40)$ ile periferaldi. Bilateral akciğer tutulumu oran1 \%57,8 $(\mathrm{n}=26)$ idi. En s1k saptanan bulgu buzlu cam dansiteleri idi $(\mathrm{n}=38, \% 84,5)$. Bunların \%35,5 (n=16)'ine konsolidasyon da eşlik etmekteydi. Vakaların \%62,2 ( $\mathrm{n}=28)$ 'sinde multifokal tutulum mevcuttu. En sik tutulan loblar alt loblar idi. Diğer nispeten sık bulgular septal kalınlaşma, subplevral çizgilenme ve hava bronkogramı idi. Hastaların ortanca nötrofil, lenfosit, D-dimer, prokalsitonin, C-reaktif protein ve laktat dehidrogenaz değerleri sırasıyla $2000 \mathrm{~mm}^{3}, 1200 \mathrm{~mm}^{3}, 1990 \mathrm{ng} / \mathrm{mL}, 30.7 \mu \mathrm{g} / \mathrm{L} 15.8 \mathrm{mg} / \mathrm{dl}, 161 \mathrm{IU} / \mathrm{L}$ idi.

Sonuç: Multifokal ve bilateral tutulum ile buzlucam dansiteleri en sık bulgulardı. Ancak genelde daha az saptanan septal kalınlaşmanın yüksek saptanması kanser hastalarında bulguların daha ciddi olabileceğini düşündürmektedir. PCR negatif vakalarda inflamatuvar markerların birçoğu daha yüksekti. Çok merkezde daha fazla hasta ile yapılacak çalışmalar kanser hastalarındaki bulguları genel popülasyonla daha iyi karşılaştırmayı sağlayacaktır. Anahtar kelimeler: COVID-19; kanser; bilgisayarlı tomografi; laboratuvar; PCR. 


\section{INTRODUCTION}

Coronavirus disease 2019 (COVID-19) was first detected in a group of patients with pneumonia in Wuhan, China in December 2019, and it is caused by severe acute respiratory syndrome coronavirus 2 (SARS-CoV-2) $(1,2)$. COVID-19 has spread rapidly across the world within a couple of months, and the World Health Organization (WHO) assessed that COVID-19 can be identified as a pandemic on 11 March 2020. COVID-19 may result in severe clinical conditions, such as pneumonia, necrotizing encephalopathy, acute respiratory distress syndrome, respiratory failure, systemic inflammatory response and sepsis, as well as in asymptomatic patients (1-3). Cancer patients have become more susceptible to COVID-19 due to immunosuppression, malnutrition and treatment-related toxicities due to the underlying disease. It has also been stated that mortality is higher in cancer patients (4). Therefore, we planned this study with the idea that CT and laboratory findings of COVID-19 may differ in cancer patients. Also, we aimed to compare these findings in cancer patients with and without positive polymerase chain reaction (PCR) results.

\section{MATERIAL AND METHODS}

This retrospective study was conducted using noncontrasted computed tomography (CT) images and laboratory values of patients infected with SARS-CoV-2 that were performed between March and September 2020 at Adana City Training and Research Hospital. The study was approved by the Ethics Committee of Adana City Training and Research Hospital (08.07.2020, 61/992) and was carried out in accordance with the provisions of the Declaration of Helsinki and the Good Clinical Practice guidelines. Pediatric patients (0-18 age) were excluded from the study. Overall, 45 patients were included in the study. Of these, 23 patients had a positive PCR test, and 22 patients' PCR test results were negative, but they had typical thorax CT features and typical clinical findings for COVID-19. Imaging was performed using a 128-detector MDCT unit (Philips Ingenuity 128, Eindhoven, The Netherlands) with technical parameters utilized as follows: $120 \mathrm{kvP}, 75-400 \mathrm{mAs}$, rotation time $0.4 \mathrm{~s}$, pitch 1.49 and slice thickness: $1 \mathrm{~mm}$. In the other center, imaging was performed using a 16-detector MDCT unit (Toshiba Alexion, Japan) with technical parameters utilized as follows: $120 \mathrm{kvP}, 100-400 \mathrm{mAs}$, rotation time $0.5 \mathrm{~s}$, pitch 1.2 and slice thickness: $1 \mathrm{~mm}$. CT images were evaluated in terms of ground glass opacity (GGO), consolidation, air bronchograms, halo and reverse halo signs (RHS), tree in bud, septal thickening, crazy paving pattern, lymphadenopathy, pleural effusion, nodules, and subpleural fibrous streaking findings, and multilobarmultifocal, unilateral or bilateral, peripheral-central and upper-lower side involvement was noted. Lymphadenopathy was considered when the short-axis diameter is $>10 \mathrm{~mm}$. The radiologic evaluation was performed by two radiologists simultaneously. The white blood cell (WBC), neutrophil, lymphocyte, D-dimer, ferritin, procalcitonin, C-reactive protein (CRP), lactate dehydrogenase (LDH), prothrombin time (PT), international normalized ratio (INR) and creatinine values of patients which were examined during the period of COVID-19 were noted.

\section{Statistical Analysis}

The data analysis was performed with SPSS v.20.0. All continuous data were presented as mean \pm standard deviation or median, interquartile range and minimum-maximum. The categorical data were presented as numbers and percentages. Shapiro Wilk's test was performed to analyze the distribution of continuous variables. Student's t-test was used to analyze variables showing normal distribution, and Mann-Whitney $U$ test was used for variables not showing normal distribution. A Chi-square test or Fisher's exact test was used to compare the categorical variables. A $\mathrm{p}$ value of $<0.05$ was considered as statistically significant.

\section{RESULTS}

Overall, 45 patients, 19 (42.2\%) female and 26 (57.8\%) male, were included in the study. The mean age was $61.4 \pm 14.6$ (range, 23-91) years (Table 1). The ratio of common parenchymal infiltration patterns was as follows: mixed GGO and consolidation $35.6 \%(n=16)$, pure GGO $48.9 \%(n=22)$ and pure consolidation $15.5 \%(n=7)$. Air bronchograms were present in $24.4 \% \quad(n=11)$ of the patients. The detailed findings are shown in Table 2.

The evaluation of involvement patterns showed that $57.8 \%$ $(n=26)$ of the patients had bilateral lung involvement and $62.2 \% \quad(n=28)$ had multifocal involvement. The most common lobe involved was the left lung lower lobe with $73.3 \%(n=33)$. The evaluation of the involved area showed that only peripheral involvement pattern was the most common $(\mathrm{n}=23,51.1 \%)$. However, both peripheral and central involvement were detected in $37.8 \%(n=17)$ of the patients. The frequency of other findings is specified in detail in Table 2.

The median WBC, neutrophil, lymphocyte, D-dimer, procalcitonin, CRP, PT, INR, LDH, creatinine and ferritin values of all patients were $9100 \mathrm{~mm}^{3}, 2000 \mathrm{~mm}^{3}, 1200$ $\mathrm{mm}^{3}, 1990 \mathrm{ng} / \mathrm{ml}, 30.7 \mu \mathrm{g} / \mathrm{L}, 15.8 \mathrm{mg} / \mathrm{L}, 12.9 \mathrm{sec}, 1.16$, $161 \mathrm{U} / \mathrm{L}, 1.00 \mathrm{mg} / \mathrm{dL}$ and $7000 \mathrm{ng} / \mathrm{mL}$, respectively.

Ferritin $(\mathrm{p}<0.001)$, procalcitonin $(\mathrm{p}<0.001)$ and creatinine $(p=0.014)$ values were significantly lower in PCR positive patients, while neutrophil $(\mathrm{p}<0.001), \mathrm{CRP}(\mathrm{p}=0.007)$ and LDH $(\mathrm{p}<0.001)$ values were significantly higher in PCR positive patients than PCR negative patients.

\section{DISCUSSION}

During the COVID-19 pandemic, cancer patients have become more susceptible to this disease. Therefore, CT and laboratory findings may differ with the general population. In a study, it was found that the WBC was between 4-10000 in $60 \%$ of the cases, and over 10000 in $25 \%$, while the mean WBC number was 5300. In our study, the mean WBC number was found to be $9100 \mathrm{~mm}^{3}$. In the same study, while the mean lymphocyte count of the patients was 990 $\mu \mathrm{g} / \mathrm{L}$, lymphopenia was observed in $50 \%$ of the patients. In our study, while the lymphocyte count was detected as $1200 \mu \mathrm{g} / \mathrm{L}$, lymphopenia was observed in $35 \%$ (4).

In different studies, it has been shown that the association of COVID-19 with solid tumors is higher than hematological malignancies. In the studies conducted by Yang et al. (4) and Meng et al. (5), it was shown that it is more common in patients with solid tumors. In our study, 43 of 45 patients were patients with solid tumors, in line with the literature. The most common accompanying solid tumor differs between studies. In the study of Yang et al. (4), 
Table 1. Demographic and clinical features of the patients

\begin{tabular}{|c|c|c|c|c|}
\hline & Total $(n=45)$ & $\operatorname{PCR}(+)(n=23)$ & PCR (-) $(n=22)$ & $\mathbf{p}$ \\
\hline \multicolumn{5}{|l|}{ Gender } \\
\hline Female & $19(42.2 \%)$ & $11(47.8 \%)$ & $7(31.8 \%)$ & \multirow{2}{*}{0.273} \\
\hline Male & $26(57.7 \%)$ & $12(52.2 \%)$ & $15(68.2 \%)$ & \\
\hline Age (years), mean \pm SD & $61.4 \pm 14.6$ & $59.1 \pm 15.8$ & $63.8 \pm 13.0$ & 0.277 \\
\hline Comorbidity & $18(40.0 \%)$ & $5(21.7 \%)$ & $13(\% 59.1)$ & 0.011 \\
\hline \multicolumn{5}{|l|}{ Cancer type } \\
\hline Lung & $16(35.5 \%)$ & $7(30.4 \%)$ & $9(40.9 \%)$ & \multirow{10}{*}{0.189} \\
\hline Breast & $7(15.6 \%)$ & $5(21.7 \%)$ & $2(9.1 \%)$ & \\
\hline Colon & $7(15.6 \%)$ & $3(13.0 \%)$ & $4(18.2 \%)$ & \\
\hline Pancreas & $3(6.7 \%)$ & $3(13.0 \%)$ & $0(0.0 \%)$ & \\
\hline Endometrium & $4(8.9 \%)$ & $2(8.7 \%)$ & $2(9.1 \%)$ & \\
\hline Larynx & $2(4.4 \%)$ & $0(0.0 \%)$ & $2(9.1 \%)$ & \\
\hline Prostate & $1(2.2 \%)$ & $1(4.3 \%)$ & $0(0.0 \%)$ & \\
\hline Kidney & $1(2.2 \%)$ & $0(0.0 \%)$ & $1(4.5 \%)$ & \\
\hline Stomach & $2(4.4 \%)$ & $2(8.7 \%)$ & $0(0.0 \%)$ & \\
\hline Lymphoma & $2(4.4 \%)$ & $0(0.0 \%)$ & $2(9.1 \%)$ & \\
\hline \multicolumn{5}{|l|}{ Symptom } \\
\hline Fever & $6(13.3 \%)$ & $4(17.4 \%)$ & $2(9.1 \%)$ & \multirow{7}{*}{0.231} \\
\hline Cough & $6(13.3 \%)$ & $1(4.3 \%)$ & $5(22.7 \%)$ & \\
\hline Dyspnea & $8(17.8 \%)$ & $3(13.0 \%)$ & $5(22.7 \%)$ & \\
\hline Diarrhea & $3(6.7 \%)$ & $1(4.3 \%)$ & $2(9.1 \%)$ & \\
\hline Headache & $2(4.4 \%)$ & $1(4.3 \%)$ & $1(4.5 \%)$ & \\
\hline None & $7(15.6 \%)$ & $6(26.1 \%)$ & $1(4.5 \%)$ & \\
\hline Multiple symptoms & $13(28.9 \%)$ & $7(30.4 \%)$ & $6(27.3 \%)$ & \\
\hline
\end{tabular}

Table 2. Computed tomography findings of the patients

\begin{tabular}{|c|c|c|c|c|}
\hline & Total $(n=45)$ & $\operatorname{PCR}(+)(n=23)$ & $\operatorname{PCR}(-)(n=22)$ & $\mathbf{p}$ \\
\hline Central & $5(11.1 \%)$ & $0(0.0 \%)$ & $5(22.7 \%)$ & 0.022 \\
\hline Peripheral & $23(51.1 \%)$ & $16(69.6 \%)$ & $7(31.8 \%)$ & 0.011 \\
\hline Central and peripheral & $17(37.8 \%)$ & $7(30.4 \%)$ & $10(45.5 \%)$ & 0.299 \\
\hline GGO & $22(48.9 \%)$ & $15(65.2 \%)$ & $7(31.8 \%)$ & 0.025 \\
\hline Consolidation & $7(15.6 \%)$ & $3(13.0 \%)$ & $4(18.2 \%)$ & 0.699 \\
\hline GGO and consolidation & $16(35.6 \%)$ & $5(21.7 \%)$ & $11(50.0 \%)$ & 0.048 \\
\hline Single lung involvement & $19(42.2 \%)$ & $9(39.1 \%)$ & $10(45.5 \%)$ & 0.668 \\
\hline Bilateral lung involvement & $26(57.8 \%)$ & $14(60.9 \%)$ & $12(54.5 \%)$ & 0.668 \\
\hline Right lung upper lobe & $17(37.8 \%)$ & $7(30.4 \%)$ & $10(45.5 \%)$ & 0.299 \\
\hline Right lung middle lobe & $20(44.4 \%)$ & $10(43.5 \%)$ & $10(45.5 \%)$ & 0.894 \\
\hline Right lung lower lobe & $29(64.4 \%)$ & $15(65.2 \%)$ & $14(63.6 \%)$ & 0.912 \\
\hline Left lung upper lobe & $12(26.7 \%)$ & $7(30.4 \%)$ & $5(22.7 \%)$ & 0.559 \\
\hline Left lung lower lobe & $33(73.3 \%)$ & $17(73.9 \%)$ & $16(72.7 \%)$ & 0.928 \\
\hline Single lobe involvement & $17(37.8 \%)$ & $9(39.1 \%)$ & $8(36.4 \%)$ & 0.848 \\
\hline Multifocal involvement & $28(62.2 \%)$ & $14(60.9 \%)$ & $14(63.6 \%)$ & 0.848 \\
\hline Halo sign & $1(2.2 \%)$ & $0(0.0 \%)$ & $1(4.5 \%)$ & 0.489 \\
\hline Reverse halo sign & $1(2.2 \%)$ & $0(0.0 \%)$ & $1(4.5 \%)$ & 0.489 \\
\hline Tree in bud sign & $1(2.2 \%)$ & $0(0.0 \%)$ & $1(4.5 \%)$ & 0.489 \\
\hline Septal thickening & $23(51.1 \%)$ & $11(47.8 \%)$ & $12(54.5 \%)$ & 0.652 \\
\hline Effusion & $12(26.7 \%)$ & $7(30.4 \%)$ & $5(22.7 \%)$ & 0.559 \\
\hline Crazy Paving pattern & $6(13.3 \%)$ & $2(8.7 \%)$ & $4(18.2 \%)$ & 0.414 \\
\hline Air bronchogram & $11(24.4 \%)$ & $4(17.4 \%)$ & $7(31.8 \%)$ & 0.260 \\
\hline Nodule & $2(4.4 \%)$ & $1(4.3 \%)$ & $1(4.5 \%)$ & 1.000 \\
\hline Subpleural streaking & $12(26.7 \%)$ & $6(26.1 \%)$ & $6(27.3 \%)$ & 0.928 \\
\hline Lymphadenopathy & $3(6.7 \%)$ & $1(4.3 \%)$ & $2(9.1 \%)$ & 0.608 \\
\hline
\end{tabular}


Table 3. Laboratory findings of the patients

\begin{tabular}{|c|c|c|c|c|}
\hline & Total $(n=45)$ & $\operatorname{PCR}(+)(n=23)$ & $\operatorname{PCR}(-)(n=22)$ & $\mathbf{p}$ \\
\hline Ferritin $(\mathrm{ng} / \mathrm{mL})$ & 7000 (12514) [30-32480] & 441 (916) [30-32480] & $11500(6275)[1000-25200]$ & $<0.001$ \\
\hline $\mathrm{WBC}\left(\mathrm{mm}^{3}\right)$ & 9100 (7100) [100-31500] & 9200 (8500) [1400-31500] & $8850(6225)$ [100-22600] & 0.658 \\
\hline Neutrophil $\left(\mathrm{mm}^{3}\right)$ & 2000 (7550) [100-27300] & 8200 (8300) [680-27300] & $850(925)$ [100-3300] & $<0.001$ \\
\hline Lymphocyte $\left(\mathrm{mm}^{3}\right)$ & $1200(1013)$ [200-4550] & 1200 (800) [200-2500] & 1067 (1135) [289-4550] & 0.510 \\
\hline Procalcitonin $(\mu \mathrm{g} / \mathrm{L})$ & $30.7(112.4)$ [0.2-407.0] & 1.5 (10.7) [0.2-125.0] & $94.1(181.3)[7.6-407.0]$ & $<0.001$ \\
\hline CRP (mg/L) & 15.8 (51.6) [1.2-405.3] & $63.0(199.8)[1.2-405.3]$ & $13.8(3.4)[11.2-30.3]$ & 0.007 \\
\hline PT & $12.9(4.4)[9-28.0]$ & $13.4(4.2)[9.0-28.0]$ & 12.4 (3.3) [10.0-26] & 0.301 \\
\hline D-dimer (ng/mL) & 1990 (3730) [272-40200] & 1500 (3740) [272-40200] & 3800 (4025) [400-30.200] & 0.069 \\
\hline INR & $1.16(0.29)[0.80-2.62]$ & $1.11(0.35)[0.80-2.40]$ & $1.17(0.23)$ [0.97-2.62] & 0.964 \\
\hline Creatinine (mg/dL) & $1.00(0.84)[0.44-18.60]$ & $0.85(0.61)$ [0.44-2.93] & $1.05(1.83)[0.70-18.60]$ & 0.014 \\
\hline $\mathrm{LDH}(\mathrm{U} / \mathrm{L})$ & $161(302)[4-7044]$ & 313 (318) [161-7044] & $20(7)[4-60]$ & $<0.001$ \\
\hline
\end{tabular}

it was mostly observed in patients with breast cancer (40\%). Likewise, in another study, it was shown that it was more common in patients with breast cancer (6). In our study, the most common accompanying malignancy was lung cancer. There are not many studies comparing PCR positive and negative cancer patients. In the study of Assaad et al. (7), lung cancer was the most common accompanying solid tumor both in the PCR positive and negative groups. Our findings also support this study, and the most common accompanying cancer type was lung cancer.

Various symptoms can be seen during the course of COVID-19 infection. Common symptoms are fever, dyspnea and cough. In addition, gastrointestinal symptoms such as diarrhea, vomiting, and neurological symptoms such as loss of smell and sensation may accompany. Studies show that the most common symptoms vary. While the most common symptoms in some studies were fever and cough $(4,6,7)$, the most common symptoms in our study were dyspnea and cough. In the study by Assaad et al. (7), the most common symptom in both PCR positive and PCR negative patients was fever. While 7 (26\%) of the PCR positive patients in our study were asymptomatic, the most common symptom in symptomatic patients was fever. While $4.5 \%(n=1)$ of the PCR negative patients were asymptomatic, the most common symptom was cough and dyspnea.

Lymphopenia (lymphocyte count $<1000 \mu \mathrm{g} / \mathrm{L}$ ) can be seen in COVID-19. The decrease in lymphocyte count in these patients suggests that the immune system response may also be poor. The rate of lymphopenia in the studies performed varies between 35-70\% (8). Lymphopenia was not detected both in the PCR positive and negative patients in our study.

In COVID-19, an increase in values such as procalcitonin and C-reactive protein, which are indicators of inflammation, can be seen (8). Procalcitonin is the prohormone of calcitonin and can be normal or elevated at the onset of the disease (9). In our study, procalcitonin and CRP values were found to be high in PCR positive and negative patients. Moreover, procalcitonin levels in the PCR negative group were statistically significantly higher than the PCR positive patients.

Ferritin is also a positive acute phase reactant and may increase in inflammation. In some studies, it has been shown that the ferritin level is higher in cancer patients compared to the normal population. In our study, ferritin level was higher in PCR negative patients compared to PCR positive patients. However, there is no clear information in the literature regarding ferritin level among PCR positive and negative patients.

When evaluated in terms of CT findings, GGO was found at a rate of $100 \%$ in a similar study, which was $84.5 \%$ in our study (10). Consolidation was detected at a rate of $14 \%$ in the same study, while it was $51.1 \%$ in our study, as a higher rate. Depending on whether the patients are in the early or late period of the infection, an organizational finding such as consolidation can be expected to vary. In this study, the rate of air bronchogram was found to be $4 \%$, which is lower than the rate of $24.4 \%$ in our study. This features can also be considered as a finding correlated with the low consolidation rates of the patients in this study. In the same study, lower lobe involvement was more common, similar to the rates in our study. Bilateral involvement was also detected at a rate of $76 \%$, which was slightly higher than the rate of $57.8 \%$ in our study. When we compared CT findings with a large review of the general population (11), GGO and bilateral involvement were common in our study as in the general population. However, while consolidation rate was $10 \%$ in this review, it was higher in our study, suggesting that the organization may be more pronounced in cancer patients. In addition, in the same study and in another large review (12), it was stated that septal thickening and subpleural streaking are rare. However, in our study, these findings were detected at $51.1 \%$ and $26.7 \%$, respectively, suggesting that lung involvement may be more severe in cancer patients.

PCR positive and negative patients in our study were also compared in terms of CT findings. There are very few studies in the literature comparing these two groups even in the general population. In our study, the presence of GGO and peripheral involvement were statistically significantly higher in the PCR positive group. Similarly, in the study conducted by Chen D et al. (13), GGO was higher in those with PCR positive. In the same study, the air bronchogram was significantly higher in the PCR positive group, but in our study, there was no difference between the two groups. There was no significant difference in terms of other findings. 


\section{CONCLUSION}

As a conclusion, COVID-19 is a disease with a relatively high fatality in the general population and may have a more severe course in cancer patients. Therefore, laboratory and CT findings vary compared to the general population. In our study, CT findings such as septal thickening, which can be detected in more severe cases, were found to be higher in cancer patients compared to the general population. However, studies with a larger number of cases are needed.

Ethics Committee Approval: The study was approved by the Ethics Committee of Adana City Training and Research Hospital (08.07.2020, 61/992).

Conflict of Interest: None declared by the authors.

Financial Disclosure: None declared by the authors.

Acknowledgements: None declared by the authors.

\section{REFERENCES}

1. Ufuk F, Savas R. Chest CT features of the novel coronavirus disease (COVID-19). Turk J Med Sci. 2020;50(4):664-78.

2. Zhu N, Zhang D, Wang W, Li X, Yang B, Song J, et al. A novel coronavirus from patients with pneumonia in China, 2019. N Engl J Med. 2020:382(8):727-33.

3. Poyiadji N, Shahin G, Noujaim D, Stone M, Patel S, Griffith B. COVID-19-associated acute hemorrhagic necrotizing encephalopathy: Imaging features. Radiology. 2020:296(2):E119-20.

4. Yang K, Sheng Y, Huang C, Jin Y, Xiong N, Jiang K, et al. Clinical characteristics, outcomes, and risk factors for mortality in patients with cancer and COVID-19 in Hubei, China: a multicentre, retrospective, cohort study. Lancet Oncol. 2020;21(7):904-13.

5. Meng Y, Lu W, Guo E, Liu J, Yang B, Wu P, et al.
Cancer history is an independent risk factor for mortality in hospitalized COVID-19 patients: a propensity score-matched analysis. J Hematol Oncol. 2020;13(1):75.

6. Robilotti EV, Babady NE, Mead PA, Rolling T, PerezJohnston R, Bernardes $\mathrm{M}$, et al. Determinants of COVID-19 disease severity in patients with cancer. Nat Med. 2020;26(8):1218-23.

7. Assaad S, Avrillon V, Fournier ML, Mastroianni B, Russias B, Swalduz A, et al. High mortality rate in cancer patients with symptoms of COVID-19 with or without detectable SARS-CoV-2 on RT-PCR. Eur J Cancer. 2020;135:251-9.

8. Lippi G, Plebani M. Laboratory abnormalities in patients with COVID-2019 infection. Clin Chem Lab Med. 2020;58(7):1131-4.

9. Meisner M. Update on procalcitonin measurements. Ann Lab Med. 2014;34(4):263-73.

10. Ramtohul T, Cabel L, Paoletti X, Chiche L, Moreau P, Noret A, et al. Quantitative CT extent of lung damage in COVID-19 pneumonia is an independent risk factor for inpatient mortality in a population of cancer patients: A prospective study. Front Oncol. 2020;10:1560.

11. Salehi S, Abedi A, Balakrishnan S, Gholamrezanezhad A. Coronavirus disease 2019 (COVID-19): A systematic review of imaging findings of 919 patients. AJR Am J Roentgenol. 2020;215(1):87-93.

12. Ye Z, Zhang Y, Wang, Huang Z, Song B. Chest CT manifestations of new coronavirus disease 2019 (COVID-19): a pictorial review. Eur Radiol. 2020;30(8):4381-9.

13. Chen D, Jiang X, Hong Y, Wen Z, Wei S, Peng G, et al. Can chest CT features distinguish patients with negative from those with positive initial RT-PCR results for coronavirus disease (COVID-19)? AJR Am J Roentgenol. 2020;[Epub ahead of print]. doi: 10.2214/AJR.20.23012. 